\title{
The Structure and Development of the young plants in Oedogonium?
}

\author{
BY
}

F. E. FRITSCH, B.Sc., PH.D.

With three Figures in the Text.

\begin{abstract}
$\rightarrow-$
ATHOUGH the young plants of Oedogonium have not $A$ infrequently been figured ${ }^{2}$ in various species, not many observations on their structure and mode of development have been published ${ }^{3}$. I propose therefore in the present paper to discuss the structure of the young plants in five species of Oedogonium 4 , obtained from different parts of the Royal Botanic Gardens at Kew.

On the other hand, the formation of the zoospores in this genus has already formed the subject of much investigation. The curious details of their liberation were first clearly described by Braun ('49, pp. I50 and I73) and Pringsheim ('58, pp. 25-29). The observations of these two investigators were so reliable, that later botanists have been able to add little thereto, and chiefly occupied themselves with theories regarding the derivation of the thin membrane, which is formed round the emerging zoospore, and within which the latter remains for a short time, when fully liberated from the zoosporangium, until the dissolution of this membrane enables

1 From the Jodrell Laboratory, Royal Botanic Gardens, Kew.

${ }^{2}$ Cf. Kützing, ' 43 , Tab. Io and I 2 ; Thuret, '50, Pl. XIX, Figs. 8 and 9; Wolle,' 87 , Pl. LXXIII, Figs. $24-30$; PI. LXXIV, Figs. I 2 and I 3 ; P1. LXXXI, Figs. 4 and 5 ; Borge, '94, Figs. 66 and 67 (Oed. diplandrum, Jur.).

3 See Pringsheim, '54, p. 70, foot-note ; Poulsen, '79; Wille, '87 ; Fritsch, '02.

4 Namely, Oed. capillare, Ktz., cardiacum (Hass.), Wittr., stagnale, Ktz., cal:areum, Cleve, and in an undetermined species from the river Severn.
\end{abstract}

[Annals of Botany, Vo1. XVI. No LXIII. September, 1902.]

$\mathrm{K} \mathrm{k}$ 
the zoospore to commence moving actively. Under abnormal circumstances the phenomena connected with the liberation of the zoospore and its germination are somewhat modified, and I shall refer to some of these modifications below.

The zoospores were generally allowed to germinate in a slow but continuous stream of water on the stage of the microscope (Zimmermann, '92, p. 3). In a few cases a weak $(2 \%)$ solution of cane-sugar was employed.

\section{The Structure of the Young Plants.}

I will commence by describing the structure of the young plants in Oed. capillare ${ }^{1}$, in which the end cell of the filaments bears a distinct pointed tip. The species was growing on a mass of Nitella syncarpa contained in a glass vessel in the Herbaceous Department. When I first observed it, numerous young plants of very variable size were attached to the sides of the vessel about the level of the water. Most of these were unicellular, but some consisted of two or even three cells (see Fritsch, 1902, Fig. 23, $f$ ) ; all were provided with a very prominent tip ${ }^{2}$, which was hollow in its lower portion and solid towards the apex. Many of these young unicellular plants had again emptied their contents without undergoing division, the upper part of the cell-wall, together with the tip, being pushed on one side like a hinged $\operatorname{lid}^{3}$; in some cases this lid became quite disconnected. Sometimes, however, no lid was formed (owing probably to abnormal external conditions), and the contents of the cell then became rounded off and surrounded themselves with a new membrane, being unable to escape as a zoospore (Fig. $25, a$ ); under these circumstances a considerable decrease in bulk usually took place, the contents only occupying a small portion of the cell. It is of interest that I once or twice found that these contents had passed over the motile stage and had germinated directly

\footnotetext{
1 The germination of the zoospores in this species formed the subject of a note in the last Number (cf. Fritsch, '02).

2 Not infrequently this tip is dilated into a slight knob towards its apex.

${ }^{3}$ Cf. Fritsch, '02, p. 4 I 4 and Fig. $23 e$.
} 
within the mother-cell (Fig. 27, c). A branched, root-like organ had been formed at the one end, but the reverse end did not bear a tip as in the normal condition. It is worthy of note that the polarity of the inner individual is just diametrically opposed to that of the mother-cell (cf. Poulsen, '79, p. 2). Usually, however, if unable to escape, the contents of these young plants die off.

The cells of the young plant have the chlorophyll arranged in longitudinal bands in the manner characteristic of the adult cells of Oedogonium. Several large pyrenoids ( $p$ in Fig. 26, $a$ and $b$ ) are present in each cell, being closely surrounded by numerous starch-grains. The nucleus-a large rounded body, about twice the size of a pyrenoid, and generally parietal in position-often shows up well without staining (cf. Fritsch, 1902, Fig. 23, $f$ ), especially in plants which have been kept indoors for a few days. With Chlor-zinc-iodide the walls of the cells and the tip, which in the fully developed young plant appears quite solid, stain blue; the same colour is taken on by the basal disc. In all the species of Oedogonium examined, I found the cellular structure of the young plants to conform to the above description, except that in some of the smaller species (e.g. Oed. calcareum) the cells have only one pyrenoid apiece. The arrangement of the chlorophyll also varies slightly-apparently only irregularly though, and according to external conditions.

The young plants in Oed. capillare were found to possess two chief types of root-ends : the first strongly branched and expanded chiefly transversely to the long axis, the second slightly or not at all branched, and greatly elongated in a longitudinal direction. The first type-the attaching-disc (Fig. 25,n ${ }^{1}$-was mostly to be found in the young plants, which were attached to a firm substratum (such as the sides of the vessel); the second type, on the contrary, occurred invariably in the young plants floating on the surface of the water or in such as were not attached to any definite object (Figs. 25, $a$ and 26, $a$ ). It is a fact that Wille ('87, p. 456)

${ }^{1}$ Cf. also Fritsch, '02, Fig. $23 f$.

$\mathrm{K} \mathrm{k} 2$ 


\section{Fritsch. - The Structure and Development of}

has already noticed that only those plants which have a firm substratum, and therefore a branched basal disc, continue to grow and divide; whereas those of the second type almost invariably form zoospores before undergoing even a single division. Wille (p. 456) pointed out that this is doubtless of
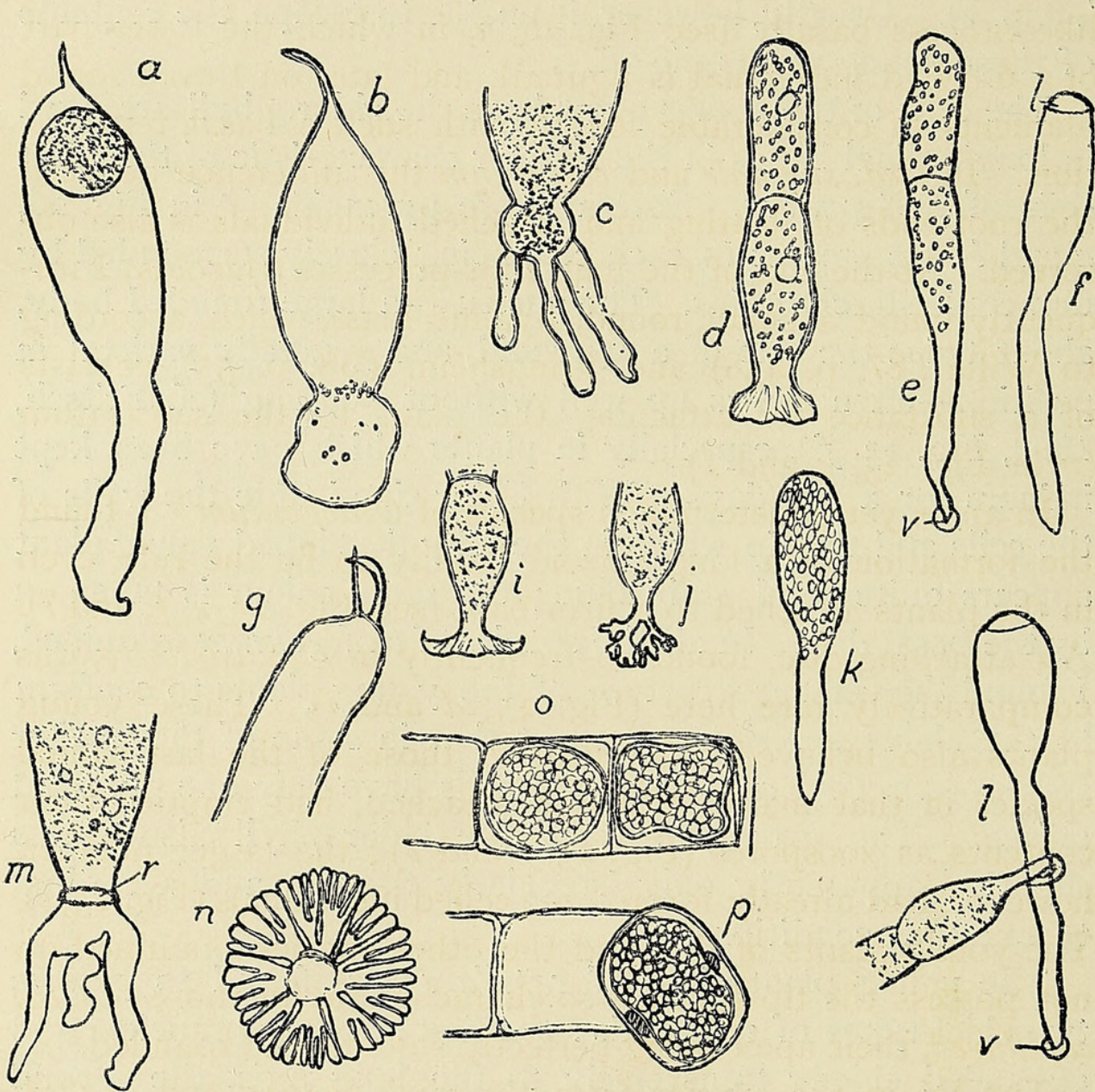

FIG. 25. $a, b, c, g$, and $n$, Oedogonium capillare, Kütz. a. Young floating plant with rhizoid; the contents have rounded themselves off. $b$. Young unicellular plant with a sack-shaped root-end. $c$. The sack-shaped root-end has grown out to form three long rhizoids. $g$. Apex of young plant, showing two tips. $n$. Attaching-disc seen from below. $d, e, f, i, j, k$ and $l$, Oedogronium spec. from River Severn. $d$. Two-celled plant with basal disc. $e$. Two-celled plant with normal type of root-end; $v=$ mass for attaching plant to substratum. $f$. Empty unicellular plant with lid, which has returned to the position it had before liberation of the contents of the cell. $i$. Basal disc with upturned ends. $j$. Branched root-end. $k$. Unicellular plant with rhizoid; not yet fully-developed. $l$. Young plant, whose rhizoid has firmly curled itself round another empty individual; $v=$ same as above. m. Oedogonium cardiacum, Wittr., usual type of root-end in floating plants; $r=$ ring of brown matter. $o, p$, Oedogonium Vaucherii, Braun. $o$. Abnormal zoospore formation. $p$. Liberation of abnormal zoospores. ( $\times 4^{\mathrm{I}} 5$. $)$ 
great value for the maintenance of the species, since only individuals which are able to attain a definite footing are capable of further development. However, this is not invariably the case, for sometimes I met with short floating filaments of from 5-10 cells, which had only a long rhizoidlike process basally (see Fig. 26, $a$, in which the lower part of a 6-celled individual is figured), and later on I even found filaments of considerable length with such a basal termination. In Oed. stagnale and calcareum this difference between the root-ends of floating and attached individuals is also observed. At the end of the long root-processes (rhizoids) I frequently found a small, round, hyaline mass, which, according to Wille $\left(' 87\right.$, p. $\left.45^{8}\right)$ and Pringsheim ('58, p. 55), consists of a substance for attaching the plant to the substratum $(v$ in Fig. 25, $e$ and $l$ ).

In an as yet undetermined species of Oedogonium ${ }^{1}$ I found the formation of a long rhizoid basally to be the rule, even in the plants attached to a firm base (see Fig. $25, e, f$, and $l$ ). An attaching-disc, found so frequently in Oed.capillare, was comparatively rare here (Fig. $25, d$ and $i$ ). These young plants also behaved differently to those of the last-named species in that many, although attached, had emptied their contents as zoospores (Fig. ${ }^{2} 5, f$ and $l$ ); the larger number; however, had already formed 2-3 celled individuals (Fig. 25, $e$ ). The young plants of this and the other species examined do not possess the tip which is so characteristic for those of Oed. capillare $^{2}$, their apex being perfectly smooth and rounded.

The lid in the species from the river Severn and in Oed. stagnale is not always so readily discerned as in Oed. capillare. The emerging zoospore seems ${ }^{3}$ to have pushed it on one side, whilst it still remained attached to the adjacent part of the

1 Growing in a glass-vessel in the Herbaceous Department, which contained a water-moss from the river Severn.

2 Tips occur at the apex of the filaments in a number of species of Oedogonium (cf. Figs. in Wolle, ' 87 , cited in foot-note 2 on p. 467 ); other species (concatenatum, var. setigerum, Huntii, ciliatum) have the apex of the filaments thinning down into a hair (cf. also Chodat, '02, p. $4^{8}$ ).

${ }^{3}$ I did not observe the emission of the zoospores in this species. 


\section{Fritsch.-The Structure and Development of}

wall at one point, as in the last-named species. But after the complete emergence of the zoospore it evidently sprang back into its original position (Fig. $25, f$ and $l$ ), and it requires careful observation of the empty mother-cell to make out the line along which the wall gave way for the emission of the contents. In other cases, however, the lid, just as in Oed. capillare, was cast off as a whole.

I found considerable variation in the form of the root-ends in Oed. capillare. The normal type of attaching-disc (Haftscheibe) is figured in Fig. $25, n$; it is no easy matter to reproduce its delicate divisions in a drawing. A sack-shaped basal end (as in Fig. 25, b) was not at all rarely observed; it was found in individuals lying freely in the water (cf. next paragraph) and under rather abnormal conditions, large numbers of bacteria having formed in the cultures. Not infrequently I found this sack-shaped root-end growing out into three or more rhizoids (Fig. 25, c), which, as it were, were searching for a substratum. Probably this is always the result of further development of the type of base shown in Fig. 25, $b$, unless the cell dies off soon (as in the case figured) or empties its contents as a zoospore.

Such a sack-shaped basal termination, which not infrequently is almost spherical, occurs as a rule and under normal conditions in Oed.cardiacum ${ }^{1}$ (Fig. 26,c). This species forms an attachingdisc very like that of Oed. capillare (cf. Fig. 27, a), provided the zoospore attains a definite substratum before coming to rest. Otherwise the sack-shaped root-end is formed, never an elongated rhizoid as in the species discussed above. These basal portions are generally only slightly dilated, and in nearly every case grow out into a number of rhizoids, which can extend for a considerable distance and are not rarely successful in reaching a definite footing (Figs. $25, m$ and $27, h$ ); in such plants with well-developed rhizoids, the original almostspherical shape of the basal end is often hard to recognize ${ }^{2}$.

${ }^{1}$ Growing on leaves of Vallisneria spiralis in the chief tank of the water-lily house.

${ }^{2}$ In a few cases a transverse wall was observed cutting off this basal part as a special root-cell from the part above. 
There is only a slight constriction at the point at which the colourless root-end goes over into the chlorophyll-containing part of the plant ; at this point, coinciding almost with the former position of the cilia, I very frequently saw a ring of brown matter extending right round the cell $(r$ in Fig. $25, m)$.

I found considerable numbers of young plants of Oed. cardiacum with this type of base floating on the surface of the water, and most of them exhibited a striking peculiarity. I found that each of these was in intimate connexion with an air-bubble of variable size. The connexion was not alone a mere cohesion, but a closer examination showed that the otherwise spherical air-bubble was drawn out to a distinct point of attachment, coinciding usually with the ring of brown matter, mentioned above (cf. Fig. $27, h ; a$ is the bubble). It would thus appear as though there were some connexion between the presence of the air-bubble and this brown matter, for the two nearly always occurred side by side. The curious shape of the bubble suggests its having been formed on the plant itself, which was by this agency enabled to float to the surface of the water ${ }^{1}$. All my attempts to elucidate this point have as yet proved unsuccessful, as the bubbles break up soon after the plant is removed from its floating position. The substance forming the brown ring is undoubtedly ferric oxide or some ferric salt. The same is very commonly found forming a coating on the basal disc of this and other species of Oedogonium. It is often present in considerable quantity at places where young plants of this genus are attached to other filamentous Algae. If treated with a solution of potassium ferrocyanide, to which a trace of hydrochloric acid has been added, this brown substance is dissolved, and in its place a precipitate of Prussian blue is formed (cf. Zimmermann, '92, p. 66).

1 Cf. also Chodat, '02, p. 92: 'C'est ainsi qu'on rencontre très communément les Ulothriciacées, les Palmellacées, les Confervacées, les Oedogoniées et les Conjugées constituant des écheveaux denses de filaments suspendus . . . par les bulles d'oxygène qu'ils exhalent au soleil. . . . ' 


\section{Fritsch.-The Structure and Development of}

In the other species examined the above-described feature was not observed, although the floating individuals are frequently found aggregated in large numbers (being then often almost radially arranged) round a single large air-bubble, which, however, exhibits a perfectly circular outline. The. floating plants form a bacteria-like scum on the surface of the water, and large numbers may be obtained by dipping the tip of the finger into the water and conveying a drop on to a slide.

It is unnecessary to mention all the variations in the types of basal-end observed in Oed. capillare; this species seemed the most variable of all in this respect. The simple rhizoid not infrequently divides irregularly after some time, thus giving rise to a structure like that figured by Poulsen (' 79 , Tab. I, Figs. 2, 3, 4, and 6); also Cohn ('54, Tab. 20). I occasionally saw the rhizoid of a young plant, which had attached itself to another (empty) one, divide up into a number of small processes, each of which twined itself round the substratum; somewhat similar cases were also found in the species from the river Severn (Fig. 25, l). A pically the filaments of $\mathrm{Oed}$. capillare sometimes terminated in a swollen cell (Fig. 26, b), the cell below then bearing a large number of caps, thus indicating that the terminal cell had not divided since its first formation. In a few cases two tips were present (Fig. $25, g$ ).

The undetermined species from the river Severn also showed a certain amount of variation in the structure of its root-end. The attaching-disc, when found here, is frequently slightly turned upwards round the edge (Fig. 25, i). Delicately branched roots are not uncommon (Fig. 25, $j$ ), and form an intermediate step between the basal-disc and the unbranched rhizoid.

In order to complete my description of the root-ends of Oedogonium I must make mention of the hemispherical basal cells, whose curious mode of development has been recently worked out by Lemmermann ('98, p. 504) and Schefferle (1901). Hirn (1900, p. I5) has shown that they occur in 
a large number of species of Oedogonium ${ }^{1}$. Hence it is surprising that I have not come across this type in the course of my investigations; possibly, however, it only develops under certain external conditions.
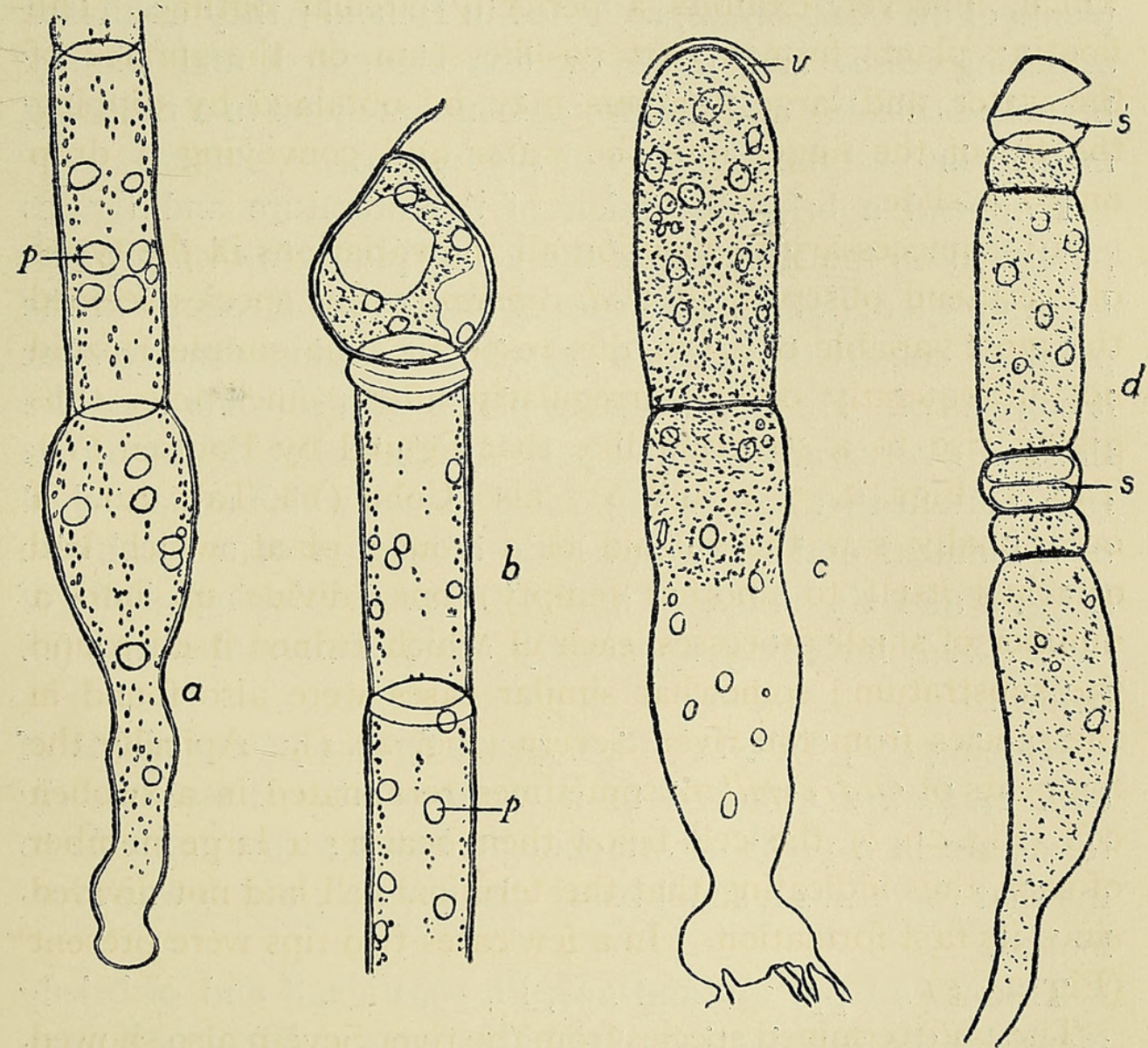

FIG. 26. $a, b$, Oedogonium capillare, Kütz. $a$. Base of a six-celled filament, showing rhizoid; the green matter extends down a considerable distance into it. $b$. Filament of young plant with swollen apical cell, active cap-formation going on in the cell below. c. Oedogonium cardiacum, Wittr., two-celled plant; the first cap has been thrown off and lies loosely at the apex. d. Oedogonium stagnale, Kütz, young two-celled plant, which is already forming spermatozoids. ( $\left.\times 3755^{\circ}\right)$

Lemmermann ('98, p. 502) mentions the occurrence of chlorophyll in the hemispherical basal cells of Oed. africanum, Lagerh., and spirogranulatum, Schmidle. I have not infrequently observed small amounts of chlorophyll in the

1 Such young plants differ from all I have described above in that the attaching portion consists of an entire cell and not of only the lowermost modified portion of a cell. 
root-ends of the species investigated, and the protoplasm extends down into them, often even into their finest branches. Sir W. Thiselton-Dyer was kind enough to let me inspect some drawings he had made about thirty years back of young plants of an Oedogonium, collected in Ireland ; they exhibited attaching-discs and more or less elongated and slightly branched rhizoids, and the protoplasm extended in a radiating manner into all the branches of the former.

I append a brief discussion of the literature and figures published on the structure of the young plants in Oedogonium: Léon de Clerc ('17, p. 462) speaks of a collar (' collet') at the point of constriction (Fig. $2^{\prime}, e$ ) without saying exactly what it consists of. He figures young plants with rhizoids very like those of Oed.cardiacum, and possibly his 'collet' is the brown ring. He further figures $\mathrm{I}-3$ celled plants, which are attached to a filament and show but little indication of a basal disc (Figs. 2 and $2^{\prime}$ ). Figs. $5^{\prime}$ and $5^{\prime \prime}$ show developing plants of Oed. Boscii, including apparently some abnormal forms (cf. below).

Kützing ('43, Tab. 10', Figs. 4-10) figures young plants of Oed. vesicatum attached to a water-plant. These merely terminate in a point of attachment, but it seems probable to me that there was a small basal disc present, which was overlooked.

Thuret ('50, pp. 226 and 227, Pl. 19, Figs. 8 and 9) briefly mentions the germination of the zoospores and figures a number of young plants, all of which have divided root-ends (crampons radiciformes); Fig. 9 shows two empty unicellular plants with lids.

Cohn ('54, Tab. 20) figures the liberation and the development of the zoospores in Oed.capillare (Fig. 16). All the young plants have more or less branched rhizoids ; no attaching-disc is shown.

Pringsheim ('54, p. 70, foot-note) describes the development of the root in a young plant in the following words: 'Die Zoosporen der Oedogonien sind nicht nur nicht nackt, sondern

\footnotetext{
${ }^{1}$ Cf. my Fig. $25 m$ and $27 h$.
} 
besitzen wie alle Zoosporen sogar zwei Membranen.... Die innere Haut der Zoospore hat wachsend die äussere Haut der Zoospore schon vor ihrem Austritt aus der Vegetationszelle so durchbrochen, wie die Tochterzelle die Mutterzelle bei der Theilung durchbricht, dadurch entsteht die Öffnung der äusseren Haut ; dieses Verhältniss ist an der keimenden Spore nachweisbar, wo jedesmal die Öffnung der äusseren Sporenhaut sichtbar wird, und zugleich auch die an ihr befestigten Cilien noch später wenigstens in Rudimenten gefunden werden können.' On Pl. IV, Figs. 26-3I, he figures the development of the young plant, exhibiting this collar round the upper part of the root-end (cf. also Hartig, '55, p. 4I 5). I have observed nothing of this nature in my cultures.

Wolle ('87) figures on Plate LXXIV, Figs. I2 and I3, one and eight-celled plants of Oed.crispum, var. rostellatum, both with an attaching-disc and a distinct tip. On Plate LXXXI, Figs. 4 and 5, a unicellular plant of Oed. autumnale with a long rhizoid and another with an attaching-disc is shown.

This is not intended to be by any means a comprehensive discussion of the literature involved. I have merely mentioned those observations which seemed to me of interest in connexion with the species discussed above.

\section{The first Cell-division in the Young Plant.}

I have already discussed (cf. Fritsch, 1902) the first celldivision in connexion with Poulsen's ${ }^{1}$ observation that the first cap of the young plant is cast off. At the time I had not yet observed this phenomenon, although I had carefully investigated this point in three species ${ }^{2}$. Since then $I$ have seen the casting-off of the first cap in a number of species, and have found that, although fairly constant for some, in others the cap is just as often retained. Thus in Oed. cardiacum the casting-off of the first cap is the rule ( $v$ in fig. 26, $c$ and 27, a), nearly all the two-celled plants showing the cap still in

${ }^{1}$ Poulsen, '79, p. I, \&c. ; cf. also Hartig, '55, p. 417; Tab. IV, Figs. I2, 13 and 14.

2 Namely, Oed.capillare, the species from the river Severn, and another undetermined species. 


\section{Fritsch.-The Structure and Development of}

position, though evidently no longer in organic contact with the rest of the cell-wall. It is frequently so closely applied to the top cell, however, that it could be easily overlooked. In other cases it is cast right off and is found lying loose in the water. I observed the structure of the first ring in this species; it agreed with the description given by Poulsen (loc. cit.), going over into the inner layer of the wall above with a gradual curve. I also followed its division into two layers and the casting-off of the outer one as a cap. In Oed. stagnale as a rule no cap is cast off, as is sometimes also the case in the first-discussed species. In Oed. calcareum I was not successful in finding a cap at the apex of the two-celled plants, although one is frequently found covering the top cell of four or five-celled individuals. It would seem as though this casting-off of the first cap depended to some extent on the shape of the apical cell; when this is acutely rounded the cap is often cast off (cf. however Poulsen, '79, p. 5).

\section{Abnormal Development of the Young Plant.}

In the course of my investigations on the young plants of Oedogonium I came across a number of interesting abnormalities, which I will now briefly discuss. Fig. $26, d$ shows a young plant of Oed. stagnale, which, although consisting of only two vegetative cells, has already commenced to form spermatozoids $(s)$. I found this individual amongst other normal ones of the same species, scattered in between the adult filaments, from which the zoospores for their formation had been derived. These adult filaments were engaged in very active spermatozoid formation, there being five or six antheridia between almost each of the vegetative cells. In this point the young plant differed from the adult, for there were only two antheridia present in each group. The conditions were evidently very suitable for spermatozoid-formation, and hence probably the precocity of the individual figured. The lower group of antheridia are still developing, in the upper group one has already liberated its contents. Such an abnormality may show how the dwarf-males originated, for the smaller 
androspores on germinating would naturally have a still more reduced vegetative portion. In fact, if we suppose the individual shown in Fig. $26 d$ to have been situated on an
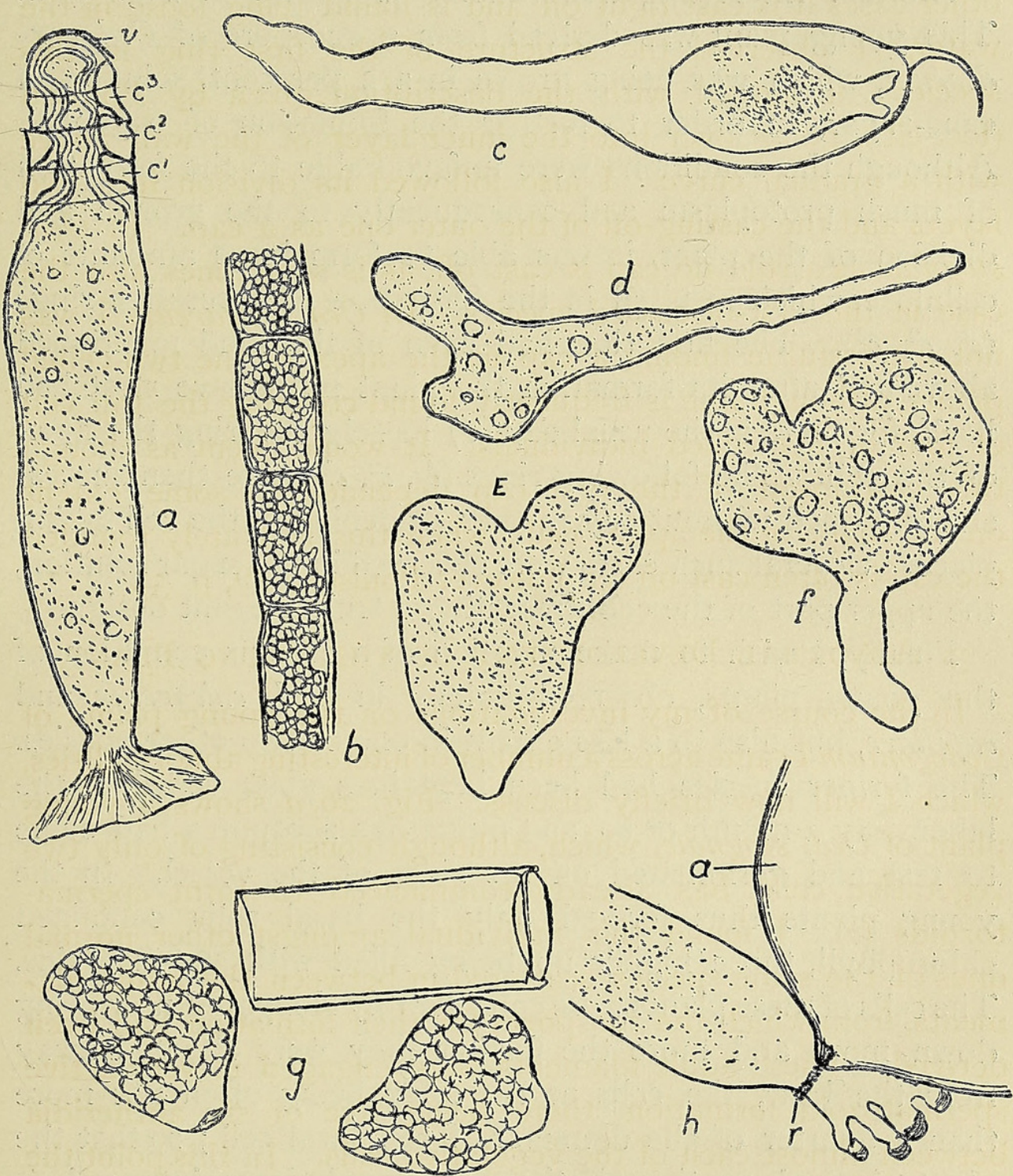

FIG. 27. $a, e, f$, and $h$, Oedogonium cardiacum, Wittr. $a$. Young plant with basal disc, which has formed successive rings, $c_{1}, c_{2}$, and $c_{3}$ without corresponding formation of transverse walls ; $v=$ first cap, which has been cast off. $e, f$. Abnormal germination of zoospores. $h$. Floating plant, in intimate connexion with an airbubble $a$, which is joined to the plant at the point where a ring of brown matter, $r$, surrounds the cell. $b$. Oedogonium Vaucherii, Braun, irregular thickenings in cells of filaments, cultivated in a $2 \%$ solution of cane-sugar. $c, g$, Oedogonium capillare, Kütz. c. Germination of a zoospore within a young unicellular plant. $g$. Abnormal germination of zoospores. d. Oedogonium stagnale, Kütz, abnormal germination under almost normal conditions. ( $\times 4^{20}$. $)$ 


\section{Fritsch.-The Structure and Development of}

oogonium, it would differ from a dwarf-male only in size and development of the vegetative structure, due to its origin from a normal, chlorophyll-bearing zoospore.

Another interesting abnormality is shown in Fig. 27, $a$. This young plant was derived from a zoospore of Oed.cardiacum, which was being grown in a 2 per cent. solution of cane-sugar, in order to further the formation of oogonia ${ }^{1}$. Although the conditions were unfavourable to the formation of much protoplasm and consequently to the growth and division of the plant, it was able to form large amounts of cellulose, which resulted in the formation of successive rings $\left(c^{1}, c^{2}, c^{3}\right)$. The first ring had been of the kind mentioned above and after its formation the plant must have stretched itself, for there is the usual cap $(v)$ loosely covering the apex of the cell. The following rings $\left(c^{3}, c^{2}, c^{1}\right)$ were then successively formed without any further stretching of the cell taking place. Several such cases were observed in the sugar solution, the upper part of the cell presenting a truly elegant design.

Finally, I wish to make mention of a curious condition of the young plants, observed chiefly in Oed. calcareum and capillare, but also to a less extent in one or two other species. The former species had been kept in a glass vessel in the laboratory a month or so, and numerous zoospores had come to rest and germinated on the sides of the vessel. In the young plants thus formed only the basal cells contained chlorophyll, those higher up being filled with starch grains. The cells of these plants were considerably elongated, narrowing down more and more the further they were situated away from the base, the cells at the apex being often not more than a quarter of the diameter of the basal cell; so that the plants looked as though they narrowed down into a hair apically, especially as the uppermost cells had generally almost lost their contents. Such a condition of Oedogonium has been recently described in America (Keller, 1901), and interpreted as a kind of resting-stage. I do not think this very probable, and rather look upon it as a gradual dying-off of

${ }^{1}$ Cf. Klebs, '96, pp. 279, 280. 
the plant. Oedogonium is one of the hardiest genera of freshwater Algae, and it is likely that unsuitable conditions would take a long time to put an end to its vital activity, unless they were extremely fatal in their action. As a matter of fact, if cultivated in very strong solutions of cane-sugar the above-described appearance can be called forth in a few days, and, although then returned to fresh water, not a single filament becomes green and active again.

A glass vessel in the Herbaceous Department contains a mass of Oed. capillare, which has been in this condition for some months, and I do not think is likely to recover. I first noticed a change in the filaments in March of this year. I then found that the (still green) contents of the cells were aggregated chiefly about the transverse walls, and sometimes so closely that these could only be recognized on a close perusal. The side-walls also were lined by a thin layer, but the whole interior of the cells was either quite empty or only contained a few strands of protoplasm. At the time of writing all the cells are absolutely colourless and many are crowded with starch-grains; the arrangement of the protoplasm, however, indicates that most are still living. As to the external conditions, which cause this change, I can say nothing; Nitella syncarpa growing in the same water is perfectly healthy, but some Closteria present are in a similar state of degeneration.

\section{Abnormal Formation of Zoospores and THEIR DEVELOPMENT.}

The adult filaments of Oedogonium almost invariably form zoospores after being kept in a slow stream of water (Zimmermann, '92, p. 3) for some time ${ }^{1}$. The emission of the zoospores takes place very abundantly for some days, but then as bacteria gradually collect in the cultures and the filaments of the Oedogonium itself become exhausted, the process slackens down again ${ }^{2}$. Under these final (abnormal) conditions the zoospores formed often present curious characters (Fig. 27, e,f, g).

1 These experiments were carried on during the months January to June, I 902.

2 Fritsch, '02, p. 4I5. 


\section{Fritsch.-The Structure and Development of}

They assume a very irregular shape on coming to rest and only move a very little distance away from the mother-cell, and some are apparently even whilst still moving surrounded by a definite membrane. As far as I could make out, germination of these abnormal zoospores does not usually take place ${ }^{1}$.

Somewhat similar phenomena were seen in a species of Oedogonium ${ }^{2}$ (Oed. Vaucherii, Braun), which was cultivated in a 2 per cent. solution of cane-sugar, placed in direct sunlight as much as possible. The contents of the cells had rounded themselves off more or less after some days (Fig. 25, o), frequently taking on exactly the shape of a zoospore in course of development (see Fig. 25, $O$; the cell on the right). However, the conditions in the sugar solution must be unfavourable to the liberation of zoospores, for in most cases the contents remained within the mother-cell, surrounding themselves with a thick membrane (of two or three layers). Only in one or two cases was the liberation of the zoospore observed (Fig. $25, p$ ), which then took place quite abnormally. It was already at that time surrounded by a thick membrane and came to rest immediately outside the sporangium. The latter dehisced in the ordinary manner, but the zoospore showed no vibrating cilia, nor was naturally the formation of the thin membrane, usually connected with the liberation of zoospores in Oedogonium, observed. If the cells are treated with a watery solution of Iodine when in this condition, neither the external wall of the cell nor the thick membrane of the zoospore is perceptibly coloured; whereas in the cavity of the cell between these there lies a substance, which is stained a deep violet and which is undoubtedly a kind of mucilage ${ }^{3}$. This pheno-

${ }^{1}$ Fig. $27 d$ shows a zoospore of Oed. stagnale, which germinated under relatively normal conditions, and which has formed a well-developed rhizoid. The irregularity at the apex amounts almost to branching.

2 From the pools in the Temperate House. The same species later on produced oogonia and antheridia in the sugar solution (cf. Klebs, '96, pp. 279, 280).

${ }^{3}$ Klebs (loc. cit., p. 264) took the appearance of this mucilage as indicating the commencement of zoospore formation. He says: 'Die Hülle hat die Eigenschaft sich mit wässeriger Iodlösung violett $z \mathfrak{u}$ färben, . . . infolgedessen erkennt man die Bildung der Zoospore auch dann, wenn diese nicht austritt . . . Gewöhnlich verfuhr ich dabei in der Weise, dass ich die Fäden kurz in konzentrierte Salpeterlösung 
menon has been observed and described by $\operatorname{Hirn}(1900$, p. I4), although he experimented with a 12 per cent. solution of cane-sugar in order to plasmolyse cells suddenly, in which zoospore formation was already going on. He considers this mucilage to be homologous with the membrane, which normally surrounds the zoospore during its liberation, but it seems to me probable that this membrane is entirely suppressed here, and that mucilage is always (even normally) present between the zoospore and the wall of the mother-cell, though probably not in such quantities as in this case. Sporangia of Oed. capillare with the zoospores half out were stained with Chlor-zinciodide, and it was found that the empty half of the cell became stained with a deep violet colour (much darker than that due to the cellulose-walls), which is undoubtedly caused by an aggregation of mucilage behind the zoospore. The latter was surrounded by the typical thin membrane. Most probably this mucilage is of use in effecting the liberation of the zoospores; at all events I do not think that it has anything to do with the membrane of the emerging zoospores.

Not all the cells of Oed. Vaucherii formed abnormal zoospores in this manner when cultivated in a 2 per cent. solution of cane-sugar; in some filaments the cell-contents merely contracted irregularly, whilst the walls presented curious and irregular thickenings (Fig. 27, $b$ ). With Iodine or Chlor-zinciodide these thickenings stain a deep reddish-brown, whereby they are clearly differentiated from the original cell-wall. I also observed such thickenings in Oed.capillare, where, however, they took on no colour with the above-mentioned reagents. These masses seem to consist of different kinds of mucilage, which is formed under abnormal conditions ${ }^{1}$ and differs from the mucilage above described as existing between the mother-cell and the zoospore. In Oed. Vaucherii the legte und dann mit Iod tötete. Dann traten an den plasmolysierten Zellen, soweit sie in Zoosporen umgewandelt waren, die violetten Hüllen deùtlich hervor.' The 'violette Huille' is in my opinion not the same as the 'Huillblase' of the zoospore.

1 These thickenings also appeared in old cultures of $\mathrm{Ced}$. capillare, in which, however, common tap-water had been employed. 


\section{Fritsch.-The Structure and Development of}

membrane of the zoospore itself sometimes presented such thickenings (Fig. 25, $p$ ), and the difference in colour between the two kinds of mucilage on the addition of Iodine is then readily perceived.

\section{Summary.}

The more important results obtained in the present paper may be briefly summarized as follows :-

I. Certain types of root-ends are characteristic for certain species of Oedogonium; thus the attaching-disc and rhizoid for Oed.calcareum, capillare, and stagnale, the rhizoid alone for the species from the river Severn, and the attaching-disc and sackshaped basal end for Oed. cardiacum.

2. The brown substance, which is so frequently found in connexion with the young plants of Oedogonium, consists of ferric oxide or of some salt thereof.

3. The casting-off of the first cap is by no means the rule in this genus, although occurring fairly constantly in some species (e.g. Oed. cardiacum).

4. The colourless state, into which the filaments of this Alga sometimes pass over, is probably a gradual dying-off of the plant.

It remains for me to express my sincere thanks to my friend, Mr. L. A. Boodle, F.L.S., for several valuable suggestions made in the course of this work. 


\section{REFERENCES TO LITERATURE.}

1. BORGE ('94) : Über die Rhizoidenbildung bei einigen fadenförmigen Chlorophyceen. Upsala, 1894. Nya tidnings actiebolags. Vol. ii.

2. BRAUN ('49): Betrachtungen über die Erscheinung der Verjüngung in der Natur. $1849-50$.

3. Chodat ('02): Algues vertes de la Suisse. Pleurococcoïdes-Chroolépoïdes.

4. CoHN ('54): Untersuchungen über die Entwickelung der mikroskop. Algen u. Pilze. Leop.-Akad, I854, Vol. xxiv, pars I.

5. FrITSCH ('02): On the Germination of the Zoospores in Oedogonium. Annals of Botany, vol. xvi, p. 4I 2 (Notes).

6. Hartig ('55): Beiträge zur Entwickelung der Pflanzenzelle. Bot. Zeitung., I 855, p. 4 I 5 .

7. Hirn ('00): Monographie u. Iconographie der Oedogoniaceen. Act. Soc. Scient. Fenn., tom. xxvii, I900.

8. Keller ('01) : A peculiar condition of Oedogonium. Proc. Acad. Nat. Sci. Philadelphia, vol. liii, Pt. III, pp. 598-60I.

9. Klebs ('96): Die Bedingungen der Fortpflanzung bei einigen Algen u. Pilzen. 1896.

10. KüTZING ('43): Phycologia generalis. 1843 .

11. Lemmermann ('98): Algologische Beiträge. IV. Süsswasseralgen der Insel Wangerooge. Abh. Nat.-Ver. Bremen. Bd. xiv, I898, p. $5^{\circ 2}$.

12. Léon de Clerc ('17): Sur la fructification du genre Prolifère. Mém. du Muséum d'Histoire nat. Paris. Vol. iii, I8I 7.

13. POULSEN ('79): Om svaermsporens spring hos en art af slægten Oedogonium. Botanisk Tidskrift, $3^{\circ}$ sér., vol. ii., I 879 , p. I.

14. Pringsheim ('54): Bau u. Bildung der Pflanzenzelle.

15. ('58): Beiträge zur Morphologie u. Systematik d. Algen. I. Morphologie der Oedogonien. Pringsh. Jahrb., vol. i, $185^{8}$, p. I.

16. SCHEFFERLE ('01) : Einige Beobachtungen über Oedogonien mit halbkugeliger Basalzelle. Ber. Deut. Bot. Ges., Bd. xix, pp. 557-563, Plate XXXI.

17. Thuret ('50): Recherches sur les zoospores des algues. Ann. Sci. Nat., $3^{\text {e }}$ sér., vol. xiv, 1850.

18. Wille ('87): Algologische Mittheilungen. V. Über das Keimen der Schwärmsporen bei Oedogonium. Pringsh. Jahrb., vol. xviii, p. 454.

19. Wolle ('87) : Freshwater Algae of the United States.

20. ZimmermanN ('92): Die botanische Mikrotechnik. 


\section{$2 \mathrm{BHL}$ Biodiversity Heritage Library}

Fritsch, Felix Eugene. 1902. "The structure and development of the young plants in Oedogonium." Annals of botany 16, 467-485. https://doi.org/10.1093/oxfordjournals.aob.a088884.

View This Item Online: https://www.biodiversitylibrary.org/item/233980

DOI: https://doi.org/10.1093/oxfordjournals.aob.a088884

Permalink: https://www.biodiversitylibrary.org/partpdf/318685

\section{Holding Institution}

Smithsonian Libraries

\section{Sponsored by}

Biodiversity Heritage Library

\section{Copyright \& Reuse}

Copyright Status: Not in copyright. The BHL knows of no copyright restrictions on this item.

This document was created from content at the Biodiversity Heritage Library, the world's largest open access digital library for biodiversity literature and archives. Visit BHL at https://www.biodiversitylibrary.org. 